\title{
FDA new drug approvals in Q2 2019
}

The most prominent approval in the second quarter of 2019 was Novartis's pioneering gene therapy for spinal muscular atrophy (SMA), Zolgensma (onasemnogene abeparvovec), a rare neuromuscular disease with a typical life expectancy of less than 2 years if untreated.

After much speculation, Zolgensma debuted with a price tag of US\$2.1 million, making it the most expensive drug so far. However, what might have been missed behind the headlines decrying its cost is that not only are payments set to be spread across 5 years, but if it does prove to be a 'one and done' treatment for SMA, it might eventually be more cost-effective than ongoing treatments such as Biogen's exon-skipping therapy Spinraza (nusinersen), which became the first SMA therapy to be approved by the FDA in 2016. Spinraza's list price is $\$ 750,000$ in the first year of treatment and then $\$ 375,000$ annually, and it had reported sales of $\$ 1.72$ billion in 2018 . However, little is currently known about the durability of the effects of gene therapy products, making costeffectiveness predictions challenging, as well as sales forecasts. At present, the consensus sales forecast for Zolgensma is $\$ 1.5$ billion in 2024 (TABLE 1).

Earlier in the quarter, AbbVie and partner Boehringer Ingelheim gained a green light from the FDA for what might be one of the biggest launches of the year, Skyrizi (risankizumab). The interleukin-23specific antibody was approved for psoriasis, and sell-side consensus currently puts 2024 sales at \$3.2 billion. Given AbbVie’s desire to reduce its reliance on its megablockbuster Humira (adalimumab) — which catalysed the $\$ 63$ billion acquisition of Allergan it announced in June - having another blockbuster approved might help, even if a percentage of sales flow to Boehringer.

Several drugs approved in the quarter were cancer drugs, highlighting the industry's continuing focus on oncology. Johnson \& Johnson's Balversa (erdafitinib), a fibroblast growth factor receptor (FGFR) kinase inhibitor for locally advanced or metastatic bladder cancer with susceptible FGFR2 and FGFR3 alterations identified by a simultaneously approved companion diagnostic, is the first drug in its class. It was granted accelerated approval in April, and is forecasted to become a blockbuster, with 2024 sales of $\$ 1.15$ billion.

Also gaining accelerated approval was Roche's Polivy (polatuzumab vedotin), a CD79b-specific antibody conjugated to the microtubule-disrupting drug monomethyl auristatin for the treatment of patients with relapsed/refractory diffuse large B cell lymphoma (DLBCL). Polivy, which was approved in combination with bendamustine, has shown impressive results in clinical trials, with complete response rates of $40 \%$ in patients with relapsed/refractory DLBCL, and is forecast to have sales of almost $\$ 1$ billion in 2024.

Finally in the oncology area, Novartis's phosphatidylinositol 3-kinase- $\alpha$ inhibitor Piqray (alpelisib) was granted a standard approval for hormone receptor-positive, HER2-negative patients with a PIK3CA mutation. Like Balversa, Piqray comes with its own companion diagnostic. Novartis will be hoping Piqray does better than its other recent breast cancer entrant, the CDK4/6 inhibitor Kisqali (ribociclib), which has had a disappointing launch since its FDA approval in 2017.

Other approvals included Pfizer's first-in-class transthyretin dissociation inhibitor Vyndaqel (tafamidis meglumine) for hereditary transthyretin-mediated amyloidosis and Amgen's first-in-class antisclerostin antibody Evenity (romosozumab) for severe osteoporosis. Vyndaqel is forecast to have sales of more than $\$ 2$ billion in 2024, but Evenity was rejected by European regulators in June, citing concerns over increased risk of cardiac events, and its 2024 forecast is less than $\$ 500$ million.

The last - and controversial approval of the quarter was for AMAG Pharmaceuticals' Vyleesi (bremelanotide), a melanocortin 4 receptor agonist for the treatment of hypoactive sexual desire disorder in premenopausal women. The drug also has a low forecast, of \$151 million in 2024, but its limited efficacy and its side effect profile suggest even these predictions are generous. Industry observers have already compared Vyleesi to Sprout Pharmaceuticals' Addyi (flibanserin), which reportedly only achieved $\$ 13$ million in sales at its 2016 peak.

\section{Competing interests}

The author declares no competing interests.

Table 1 | Selected FDA new drug approvals in Q2 2019

\begin{tabular}{|c|c|c|c|c|}
\hline Date & $\begin{array}{l}\text { Drug (brand name; } \\
\text { company) }\end{array}$ & Properties & Indication & $\begin{array}{l}2024 \text { global } \\
\text { sales forecast }\end{array}$ \\
\hline 9 April & $\begin{array}{l}\text { Romosozumab } \\
\text { (Evenity; Amgen) }\end{array}$ & Sclerostin antibody & Osteoporosis & $\$ 320$ million \\
\hline 12 April & $\begin{array}{l}\text { Erdafitinib (Balversa; } \\
\text { Johnson \& Johnson) }\end{array}$ & FGFR antagonist & Bladder cancer & $\$ 1,150$ million \\
\hline 23 April & $\begin{array}{l}\text { Risankizumab (Skyrizi; } \\
\text { AbbVie) }\end{array}$ & IL-23 antibody & Psoriasis & $\$ 3,196$ million \\
\hline 3 May & $\begin{array}{l}\text { Tafamidis meglumine } \\
\text { (Vyndaqel; Pfizer) }\end{array}$ & $\begin{array}{l}\text { TRR dissociation } \\
\text { inhibitor }\end{array}$ & Amyloidosis & $\$ 2,108$ million \\
\hline 24 May & $\begin{array}{l}\text { Alpelisib (Piqray; } \\
\text { Novartis) }\end{array}$ & PI3Ka alpha inhibitor & Breast cancer & \$821 million \\
\hline 24 May & $\begin{array}{l}\text { Onasemnogene } \\
\text { abeparvovec } \\
\text { (Zolgensma; Novartis) }\end{array}$ & SMN1 gene therapy & $\begin{array}{l}\text { Spinal muscular } \\
\text { atrophy }\end{array}$ & $\$ 1,569$ million \\
\hline 10 June & $\begin{array}{l}\text { Polatuzumab vedotin } \\
\text { (Polivy; Roche) }\end{array}$ & $\begin{array}{l}\text { CD79b antibody } \\
\text { conjugated to } \\
\text { monomethyl auristatin }\end{array}$ & $\begin{array}{l}\text { Non-Hodgkin } \\
\text { lymphoma }\end{array}$ & \$912 million \\
\hline 27 June & $\begin{array}{l}\text { Bremelanotide } \\
\text { (Vyleesi; AMAG } \\
\text { Pharmaceuticals) }\end{array}$ & $\mathrm{MC}_{4}$ receptor agonist & $\begin{array}{l}\text { Hypoactive sexual } \\
\text { desire disorder }\end{array}$ & $\$ 151$ million \\
\hline
\end{tabular}

FGFR, fibroblast growth factor receptor; IL, interleukin; $\mathrm{MC}_{4}$, melanocortin 4; PI3Ka, phosphatidylinositol 3kinase- $\alpha$; SMN1, survival of motor neuron 1; TTR, transthyretin. Source: EvaluatePharma June 2019, Evaluate Ltd. 